Buletin Ilmiah Math. Stat. dan Terapannya (Bimaster)

Volume 09, No. 1 (2020), hal 137 - 144.

\title{
ANALISIS TEKNIKAL PADA INVESTASI TRADING EMAS ONLINE DENGAN STOCHASTIC OSCILLATOR
}

\author{
Mila Damayanti, Setyo Wira Rizki, Hendra Perdana
}

\begin{abstract}
INTISARI
Investasi pada hakikatnya merupakan penempatan sejumlah dana dengan harapan memperoleh keuntungan di masa mendatang. Umumnya investasi dibedakan menjadi dua, yaitu investasi pada asetaset finansial (financial assets) dan investasi pada aset-aset riil (real assets). Salah satu investasi yang bergerak pada investasi aset- aset finansial di pasar modal yaitu investasi trading emas online. Analisis teknikal merupakan salah satu teknik yang digunakan dalam melakukan analisis pergerakan harga saham. Terdapat banyak indikator yang dapat digunakan pada analisis teknikal, salah satunya indikator stochastic oscillator. Stochastic oscillator mempunyai dua garis yang disebut dengan garis \%K dan garis $\%$ D. Tujuan dari penelitian ini untuk menentukan sinyal jual dan sinyal beli pada investasi trading emas serta mengetahui seberapa besar keuntungan yang diperoleh dalam menentukan sinyal jual dan sinyal beli menggunakan indikator stochastic oscillator. Penelitian ini menggunakan data harian harga emas yang didapat dari perusahaan PT. Merdeka Copper Gold Tbk (MDKA) dimana periode yang diambil dari periode September sampai dengan Oktober 2019. Terdapat dua sinyal untuk menjual emas dan tidak ada sinyal untuk membeli emas pada periode dua bulan terakhir. Simulasi dilakukan dengan asumsi modal awal sebesar Rp100.000.000,00. Keuntungan terbesar untuk menjual emas dalam periode dua bulan yaitu pada tanggal 23 September 2019 dengan keuntungan sebesar 4.035.171,35 (4,04\%).
\end{abstract}

Kata Kunci : Investasi, indikator, sinyal, MDKA.

\section{PENDAHULUAN}

Investasi adalah sebuah bisnis yang memberikan keuntungan tetapi juga berisiko. Semakin tinggi keuntungan yang dicapai dalam berinvestasi maka semakin tinggi pula risiko yang akan di hadapi sehingga diperlukan manajemen risiko yang sesuai agar dapat meminimalkan risiko. Salah satu alternatif investasi yang memberikan keuntungan yang tinggi adalah investasi yang bergerak di bidang perdagangan emas. Trading emas online merupakan pembelian kontrak emas online lewat broker yang emas fisiknya disimpan oleh Bullion Association di London. Harga emasnya mengikuti New York Merchantile Exchange (pasar komoditas terbesar di dunia) Amerika[1].

Secara umum terdapat dua analisis saham yaitu analisis fundamental dan analisis teknikal. Analisis fundamental adalah analisis mendalam yang menitikberatkan pada laporan keuangan dengan melihat sisi laba, aset, kemampuan melunasi utang jangka pendek dan kelancaran usaha[2]. Analisis teknikal adalah analisis pergerakan saham melalui data histori pembukaan, penutupan, harga tertinggi, harga terendah dan volume perdagangan suatu saham setiap saat. Pada dasarnya analisis teknikal sangat dibutuhkan guna menentukan kapan harus membeli saham dan kapan harus menjualnya. Dengan adanya analisis teknikal bisa mendapatkan keuntungan yang optimal juga dapat mengurangi resiko kerugian lebih dalam[3].

Penelitian ini memfokuskan pada indikator stochastic oscillator (SO). Indikator ini diciptakan oleh George C. Lane pada akhir tahun 1950-an. SO adalah indikator oscillator sederhana yang mengukur momentum. SO mempunyai dua garis yang disebut dengan garis $\% \mathrm{~K}$ dan garis $\% \mathrm{D}$. Garis $\% \mathrm{~K}$ adalah garis utama yang disebut dengan signal line. $\% \mathrm{~K}$ adalah garis yang menggambarkan posisi relatif, serta harga penutupan terhadap range harga tertinggi dan terendah dalam periode pengamatan. Sedangkan \%D merupakan trigger line yang tidak lain merupakan moving average dari \%K. 
SO akan menunjukkan saat-saat dimana pergerakan harga telah mencapai keadaan overbought (jual) atau oversold (beli)[4].

Tujuan dari penelitian ini adalah untuk menentukan sinyal jual dan sinyal beli pada trading emas online dan mengetahui keuntungan yang diperoleh dalam menentukan sinyal jual dan sinyal beli menggunakan indikator SO. Data yang digunakan berupa data harga emas yang diperoleh dari perusahaan PT. Medan Copper Gold Tbk dari tanggal 2 September sampai dengan 31 Oktober 2019. Perhitungan indikator SO menggunakan data harga penutupan, harga pembukaan, harga tertinggi dan harga terendah.

\section{INVESTASI}

Umumnya investasi dibedakan menjadi dua, yaitu investasi pada aset-aset finansial dan investasi pada aset-aset riil. Investasi pada aset-aset finansial dilakukan di pasar uang, diantaranya berupa sertifikat deposito, commercial paper, dan surat berharga pasar uang. Investasi juga dapat dilakukan di pasar modal, diantaranya berupa saham, obligasi, waran, dan opsi. Investasi pada aset-aset riil dapat berbentuk pembelian aset produktif, pendirian pabrik, pembukaan pertambangan, dan pembukaan perkebunan[5].

Adapun pihak-pihak yang melakukan investasi disebut investor. Melakukan investasi di pasar modal diperlukan pengetahuan yang cukup, pengalaman, serta naluri bisnis untuk menganalisis efekefek mana yang akan dibeli, mana yang akan dijual, dan mana yang tetap dimiliki. Sebagai investor harus rasional dalam menghadapi pasar jual beli saham. Selain itu, investor harus mempunyai ketajaman perkiraan masa depan investasi yang akan dibeli atau dijual.

\section{INVESTASI TRADING EMAS ONLINE}

Investasi trading emas online bersifat lebih aktif dari investasi emas fisik. Investasi emas bisa disebut investasi yang sedang tren di kalangan masyarakat utamanya para investor. Berikut adalah ciriciri investasi trading emas online:

1. Menggunakan one price system (pada saat yang sama harga jual-harga beli);

2. Satuan harga dalam dollar Amerika (US \$);

3. Satuan bobot TO (troy ounce);

4. Minimal Transaksi 1 lot atau 100 TO sama dengan 3,1 kg;

5. Trading date: Senin-Jumat.

Broker adalah orang yang berfungsi sebagai perantara antara investor sebagai pelaku pasar dengan pasar komoditi. Broker meneruskan pesanan ke clearing house untuk diperdagangkan di pasar komoditi, sedangkan clearing house adalah lembaga yang merupakan salah satu sarana dalam future market yang berfungsi memperlancar terjadinya transaksi antara pelaku pasar di future market [6].

\section{PASAR MODAL}

Pasar modal dapat didefinisikan sebagai pasar untuk berbagai instrumen keuangan (sekuritas jangka panjang yang dapat diperjualbelikan, baik dalam bentuk utang ataupun modal sendiri, baik yang diterbitkan oleh pemerintah, publik authorities, maupun perusahaan swasta). Tempat dimana terjadinya jual beli sekuritas disebut dengan bursa efek. Oleh karena itu, bursa efek merupakan arti dari pasar modal secara fisik[6].

Pasar modal merupakan satu bentuk kegiatan dari lembaga keuangan non bank sebagai sarana untuk memperluas sumber-sumber pembiayaan perusahaan. Aktivitas ini terutama ditujukan bagi perusahaan yang membutuhkan dana dalam jumlah besar dan penggunaannya diperlukan untuk jangka panjang. Dana dalam jumlah besar dan penggunaan dalam jangka panjang sering kali tidak dapat dipenuhi oleh lembaga perbankan sehingga sumber dana alternatif dapat dicari melalui pasar modal. 


\section{ANALISIS TEKNIKAL}

Analisis teknikal adalah suatu metode pengevaluasian saham, komoditas, ataupun sekuritas lainnya dengan cara menganalisis statistik yang dihasilkan oleh aktivitas pasar di masa lampau guna memprediksi pergerakan harga di masa mendatang[7]. Tujuan dari analisis teknikal adalah memperhitungkan supply dan demand dari sebuah saham sehingga dapat diprediksi. Analisis teknikal ini sering juga disebut dengan chartist, karena para analisisnya melakukan studi dengan menggunakan grafik. Beberapa informasi penting dilakukannya analisis teknikal, antara lain:

\section{Support dan resistance level}

Support adalah kisaran harga di mana pada level atau kisaran tersebut diperkirakan permintaan cukup kuat untuk dapat menahan harga jatuh lebih lanjut. Logika sederhananya adalah ketika harga turun mendekati kisaran support, menyebabkan meningkatnya keinginan investor untuk membeli saham tertentu. Ketika harga menyentuh kisaran tersebut maka diperkirakan demand akan melebihi supply sehingga penurunan harga akan tertahan. Resistance adalah tingkat harga dimana kecenderungan menjual pada kisaran tersebut diperkirakan cukup kuat untuk menahan laju kenaikan harga. Logika dasarnya adalah bahwa jika terjadi kenaikan harga yang mendekati kisaran resistance, maka kecenderungan trader ataupun investor untuk menjual semakin meningkat.

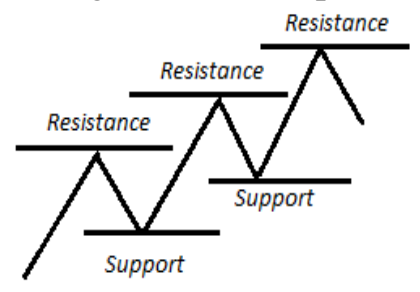

Gambar 1 Resistance dan Support

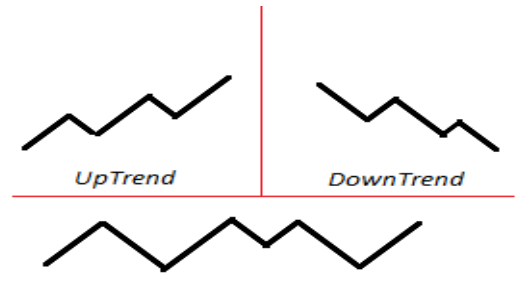

Sideways

Seperti yang dapat dilihat pada Gambar 1 terdapat pola zig-zag yang menunjukkan pergerakan naik, ketika pasar bergerak ke atas dan kemudian kembali ke bawah, maka titik tertinggi yang dicapai sebelum harga kembali turun adalah resistance. Kemudian, ketika harga naik kembali, maka titik terendah yang dicapai sebelum harga kembali naik disebut support.

\section{Tren Pasar}

Tren adalah pola kecenderungan pergerakan harga saham ke arah tertentu dari waktu ke waktu. Perdagangan saham dikenal dengan tiga tren yaitu, tren naik, tren turun, dan kondisi biasa, hal ini dapat dilihat pada Gambar 2. Kondisi uptrend terjadi ketika harga mencapai puncak yang lebih tinggi dan juga lembah yang tinggi dalam grafik. Downtrend sendiri terjadi ketika harga menyentuh lembah yang lebih rendah dan puncak yang lebih rendah dalam grafik. Sedangkan sideways terjadi ketika harga perdagangan dalam rentang tertentu tanpa adanya pergerakan ke atas maupun ke bawah secara signifikan.

\section{CANDLESTICK CHART}

Charts adalah sebuah gambar yang fungsi utamanya menunjukkan riwayat pergerakan nilai harga saham pada suatu periode waktu tertentu, sehingga dibutuhkan sebagai alat utama untuk melakukan suatu analisis secara teknikal. Candlestick adalah bagian dasar terpenting agar mampu membaca pergerakan saham. Candlestick pada Gambar 3 dapat memperlihatkan empat nilai sekaligus, yaitu harga pembukaan, harga penutupan, harga tertinggi, dan harga terendah dalam suatu periode waktu tertentu. Serta dengan adanya body akan lebih mudah melihat apakah market tersebut naik atau market turun dan seberapa jauh kenaikan atau penurunannya. Seberapa jauh usaha kenaikan dan penurunannya dapat dilihat dari panjangnya kaki atau shadow pada candle tersebut. Ada dua warna yang digunakan, merah dan hijau. Candlestick berwarna hijau menunjukkan harga penutupan lebih tinggi dari harga pembukaan, sedangkan warna merah adalah sebaliknya[2]. 


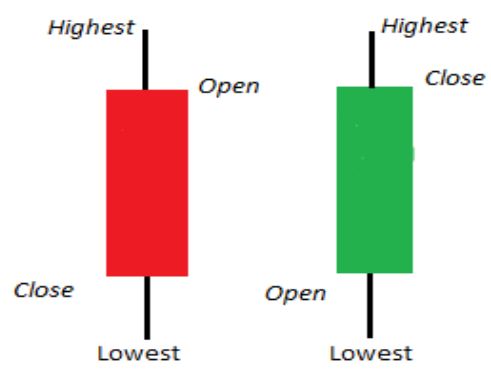

Gambar 3 Candlestick

\section{INDIKATOR STOCHASTIC OSCILLATOR}

Indikator stochastic oscillator (SO) merupakan salah satu indikator yang bersifat mendahului yang mana indikator ini merupakan indikator yang digunakan untuk mengetahui momentum kondisi pasar[7]. George Lane adalah orang yang pertama kali mengenalkan indikator SO yang mana digunakan untuk menentukan lokasi dari penutupan harga sekarang terhadap wilayah titik rendah harga selama periode waktu tertentu. SO mempunyai dua garis yang disebut dengan garis $\% \mathrm{~K}$ dan garis $\% \mathrm{D}$. Garis $\% \mathrm{~K}$ adalah garis utama yang disebut dengan signal line. Garis ini menggambarkan posisi relatif, serta harga penutupan terhadap range harga tertinggi dan terendah dalam periode pengamatan. Garis \%D merupakan trigger line yang tidak lain merupakan rata-rata bergerak sederhana dari \%K. Zona overbought yaitu ketika di atas level 80, sedangkan di bawah level 20 dinyatakan sebagai oversold. Perpotongan kedua garis inilah yang akan menghasilkan sinyal jual atau sinyal beli. Sinyal beli muncul apabila di zona oversold garis $\% \mathrm{~K}$ memotong ke atas garis $\% \mathrm{D}$. Sinyal jual apabila di zona overbought, garis \% $\mathrm{K}$ memotong ke bawah garis \% $\mathrm{D}[4]$.

Nilai $\% \mathrm{~K}$ dan $\% \mathrm{D}$ dari SO dapat dihitung menggunakan formulasi, sebagai berikut:

$$
\begin{aligned}
& \% \mathrm{~K}(\mathrm{t})=\frac{\text { Harga penutupan }(\mathrm{t})-\text { Harga terendah }(t \text { hari })}{\text { Harga tertinggi }(t \text { hari })-\text { Harga terendah }(t \text { hari })} \times 100 \% \\
& \% \mathrm{D}=3 \text { Periode moving average dari } \% K
\end{aligned}
$$

Moving average (MA) dihitung dengan mengambil nilai rata-rata dari harga suatu sekuritas pada rentang waktu tertentu. Diberikan sejumlah data saham, maka MA pada $t$ periode sebagai berikut[7]:

$$
M A(t)=\frac{\% K_{t}+\% K_{t-1}+\% K_{t-2}}{3}
$$

\section{ATURAN-ATURAN UMUM DALAM ANALISIS STOCHASTIC OSCILLATOR}

Informasi yang dapat diberikan oleh alat analisis SO ini, pada dasarnya memiliki kemiripan dengan indikator relative strength index (RSI), yaitu indikasi akan terjadi overbought atau oversold. Namun dibanding RSI, SO memiliki beberapa keunggulan, antara lain sensitivitas yang lebih tinggi dan informasi arah tren melalui crossover antara garis $\% \mathrm{~K}$ dan $\% \mathrm{D}$. SO biasanya bekerja dengan baik pada saat pasar sedang dalam keadaan sideways. Ada beberapa aturan umum dalam menggunakan SO, yaitu:

\section{Informasi overbought dan oversold}

Suatu aset yang harganya naik tajam dalam periode yang sangat singkat sering disebut overbought. Oversold adalah kondisi ketika harga aset jatuh tajam di bawah nilai fundamental. Kondisi ini biasanya akibat dari reaksi berlebihan. Aset yang mengalami penurunan tajam selama periode singkat disebut oversold. Secara teoritis, titik oversold dalam analisis SO akan berada di bawah level 20, sedangkan titik overbought akan terjadi di atas level 80. Sinyal jual muncul ketika SO telah berada di area overbought Sebaliknya, sinyal beli muncul ketika SO telah berada di area oversold. 


\section{Crossover}

Kondisi crossover pada analisis SO adalah jika terjadi perpotongan antara garis $\% \mathrm{~K}$ dan $\% \mathrm{D}$. Jika garis $\% \mathrm{~K}$ memotong garis $\% \mathrm{D}$ dari bawah, hal ini mengindikasikan kondisi bullish. Jika garis $\% \mathrm{~K}$ memotong garis $\% \mathrm{D}$ dari atas, maka hal ini akan mengindikasikan terjadinya bearish trend. Perbedaan antara informasi yang dihasilkan kondisi oversold dan overbought dengan informasi yang dihasilkan melalui kondisi crossover pada SO terletak dari panjangnya trend yang dikonfirmasikan. Informasi yang dihasilkan oleh kondisi overbought dan oversold lebih mencerminkan trend jangka panjang, sementara kondisi bullish dan bearish crossover memberikan arah pergerakan trend jangka pendek

\section{Bullish atau bearish centerline}

Seperti halnya dengan indikator oscillator lainnya, SO juga memiliki aturan bullish dan bearish centerline. Jika garis $\% \mathrm{~K}$ memotong level 50 dari bawah, maka hal ini menunjukkan posisi bullish centerline, sementara jika garis $\% \mathrm{~K}$ memotong level 50 dari atas, maka hal ini menunjukkan posisi bearish centerline [4].

\section{STUDI KASUS}

Data yang digunakan dalam penelitian ini merupakan data sekunder yang diperoleh dari data historis harga emas yang berlaku di dunia, dan untuk mendapatkannya penulis mengadakan pengambilan data dan informasi di salah satu perusahan bursa saham dan futures, yakni di PT. MDKA. Data harga emas ini meliputi harga pembukaan, harga tertinggi, harga terendah, dan harga penutupan. Sumber data yang digunakan diperoleh dari yahoo.finance.com.

Tabel 1 Statistik deskriptif

\begin{tabular}{|c|c|c|c|c|}
\hline & Jumlah & Rata-rata & Minimal & Maksimal \\
\hline Pembukaan & 44 & $1.241,14$ & 1.165 & 1.300 \\
\hline Tertinggi & 44 & $1.257,84$ & 1.190 & 1.335 \\
\hline Terendah & 44 & $1.216,59$ & 1.085 & 1.270 \\
\hline Penutupan & 44 & $1.237,95$ & 1.150 & 1.295 \\
\hline
\end{tabular}

Tabel 1 menjelaskan statistik deskriptif dari data yang didapat dari perusahaan PT. MDKA dimana periode yang diambil dari periode September sampai dengan Oktober 2019. Berdasarkan Tabel 1 dapat dilihat bahwa terdapat 44 data saham yang meliputi harga pembukaan, harga tertinggi, harga terendah dan harga penutupan. Banyak data saham tersebut merupakan jumlah hari kerja dari 2 September hingga 31 Oktober 2019.

\section{ANALISIS STOCHASTIC OSCILLATOR}

Strategi menggunakan indikator ini adalah jika $\% \mathrm{~K}$ menembus ke atas dari \%D merupakan sinyal beli. Sebaliknya jika $\% \mathrm{~K}$ menembus ke bawah dari $\% \mathrm{D}$ maka peluang adanya pola pembalikan arah. Garis $\% \mathrm{~K}$ merupakan garis yang menjadi pengamat bagi user pada saat berada di posisi lebih kecil atau sama dengan 20 (merupakan posisi oversold). Sebaliknya jika nilai lebih besar atau sama dengan 80 poin merupakan potensi adanya overbought yang berarti jangka pendek berpeluang melemah. Garis $\% \mathrm{~K}$ adalah garis yang menggambarkan posisi relatif, serta harga penutupan terhadap range harga tertinggi dan terendah dalam periode pengamatan. Sedangkan \%D merupakan trigger line yang tidak lain merupakan SMA dari \%K. Periode standar SO yang direkomendasikan oleh penemunya adalah periode 14. Namun, pada menu software umumnya periode ini dapat digeser, misalnya dikurangi untuk mendapatkan sinyal yang lebih cepat atau sensitif, ataupun ditingkatkan untuk meredam bad signals. Periode yang digunakan dalam perhitungan SO untuk \%K dalam penelitian ini adalah 14 periode dan untuk \%D merupakan tiga periode moving average dari \% K dapat dilihat pada Tabel 2 berikut: 
Tabel 2 Perhitungan stochastic oscillator

\begin{tabular}{|c|c|c|c|c|c|c|}
\hline Tanggal & Pembukaan & Tertinggi & Terendah & Penutupan & $\% \mathrm{~K}$ & $\% \mathrm{D}$ \\
\hline 9/2/2019 & 1.220 & 1.230 & 1.190 & 1.210 & & \\
\hline $9 / 3 / 2019$ & 1.220 & 1.270 & 1.210 & 1.250 & & \\
\hline $9 / 4 / 2019$ & 1.260 & 1.270 & 1.245 & 1.245 & & \\
\hline $9 / 5 / 2019$ & 1.240 & 1.255 & 1.210 & 1.225 & & \\
\hline $9 / 6 / 2019$ & 1.230 & 1.230 & 1.200 & 1.220 & & \\
\hline $9 / 9 / 2019$ & 1.230 & 1.235 & 1.215 & 1.220 & & \\
\hline $9 / 10 / 2019$ & 1.220 & 1.225 & 1.200 & 1.205 & & \\
\hline $9 / 11 / 2019$ & 1.200 & 1.220 & 1.200 & 1.200 & & \\
\hline $9 / 12 / 2019$ & 1.200 & 1.200 & 1.085 & 1.165 & & \\
\hline $9 / 13 / 2019$ & 1.180 & 1.190 & 1.120 & 1.150 & & \\
\hline $9 / 16 / 2019$ & 1.165 & 1.210 & 1.155 & 1.210 & & \\
\hline $9 / 17 / 2019$ & 1.215 & 1.215 & 1.185 & 1.190 & & \\
\hline $9 / 18 / 2019$ & 1.195 & 1.245 & 1.190 & 1.235 & & \\
\hline $9 / 19 / 2019$ & 1.235 & 1.245 & 1.220 & 1.240 & 83,7838 & \\
\hline $9 / 20 / 2019$ & 1.240 & 1.290 & 1.240 & 1.270 & 90,2439 & \\
\hline $9 / 23 / 2019$ & 1.275 & 1.325 & 1.270 & 1.295 & 87,5 & 87,1759 \\
\hline $9 / 24 / 2019$ & 1.300 & 1.310 & 1.270 & 1.270 & 77,0833 & 84,9424 \\
\hline $9 / 25 / 2019$ & 1.270 & 1.295 & 1.270 & 1.290 & 85,4167 & 83,3333 \\
\hline$\vdots$ & $\vdots$ & $\vdots$ & $\vdots$ & $\vdots$ & $\vdots$ & $\vdots$ \\
\hline $10 / 30 / 2019$ & 1.210 & 1.220 & 1.165 & 1,210 & 33,3333 & 24,9042 \\
\hline $10 / 31 / 2019$ & 1.210 & 1.210 & 1.185 & 1.195 & 22,2222 & 23,1162 \\
\hline
\end{tabular}

Berdasarkan Tabel 2 diperoleh hasil perhitungan \%K yaitu berada di posisi 83,78\% dari jarak harga terendah dengan harga tertinggi dengan harga penutupan 1.240. Selanjutnya didapatkan hasil perhitungan $\% \mathrm{D}$ atau tiga periode SMA dari $\% \mathrm{~K}$ sebesar $87,17 \%$. Garis $\% \mathrm{~K}$ dan $\% \mathrm{D}$ pada periode selanjutnya dapat dihitung dengan menggunakan Persamaan (1) dan Persamaan (2).

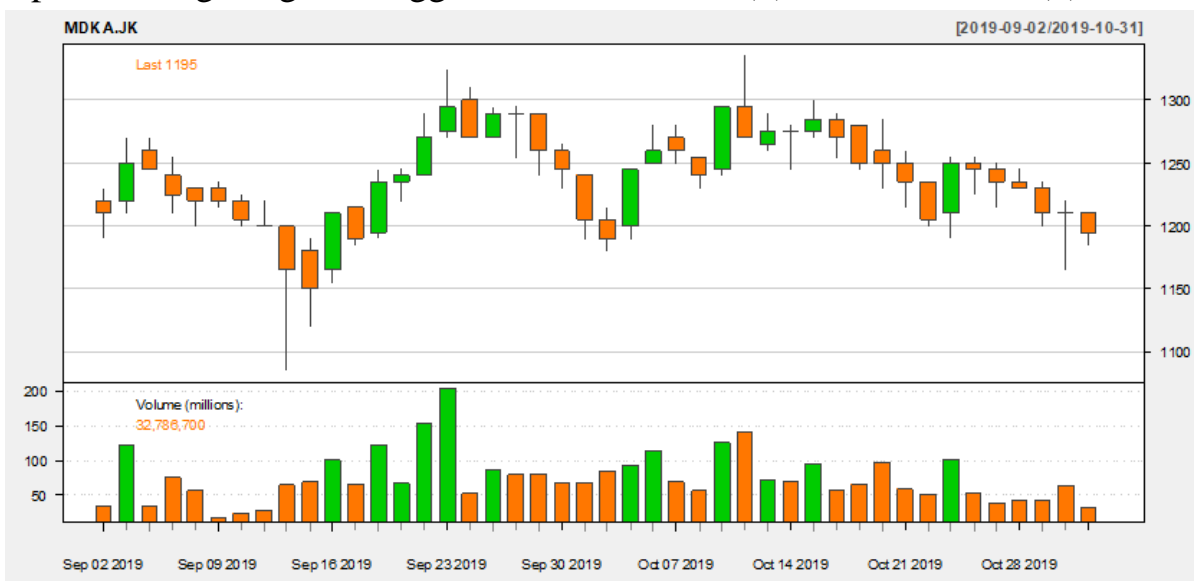

Gambar 4 Grafik candlestick dari trading emas PT. MDKA

Candlestick berwarna merah berarti harga penutupan lebih rendah dari harga pembukaan yang menunjukkan sinyal akan turun (bearish). Sedangkan untuk candlestick berwarna hijau berarti harga penutupan lebih tinggi dari harga pembukaan yang menunjukkan sinyal akan naik (bullish). Volume untuk mengetahui besarnya transaksi pada suatu waktu. Semakin besar volume maka akan semakin mendorong pergerakan harga ke arah yang sesuai dengan transaksi. Harga penutupan terakhir yang secara konsisten semakin mendekati harga tertinggi mengindikasikan dorongan beli atau disebut dengan akumulasi. Harga penutupan terakhir yang mendekati harga terendah menandakan kondisi jual 
Berikut ini adalah hasil perhitungan menggunakan software $R$ dapat dilihat pada Gambar 5 sebagai berikut:

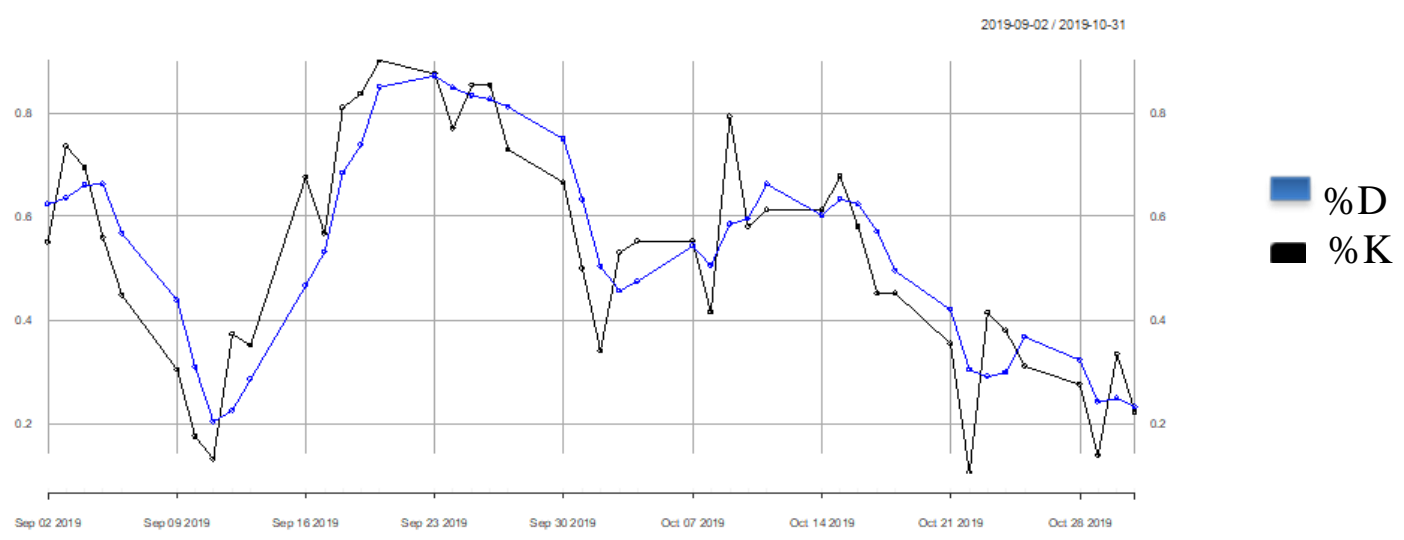

Gambar 5 Line chart menggunakan stochastic oscillator

Berdasarkan Gambar 5 didapatkan informasi bahwa pada tanggal 23 September 2019 saat itu terdapat garis $\% \mathrm{~K}$ memotong dari atas ke bawah garis $\% \mathrm{D}$, maka hal ini akan mengindikasikan terjadinya bearish tren. Selanjutnya garis $\% \mathrm{~K}$ dan $\% \mathrm{D}$ berada di atas level 80 sehingga terjadi overbought. Sinyal jual muncul ketika SO telah berada di area overbought. Harga penutupan trading emas pada tanggal 23 September 2019 sebesar Rp1,295.00 dengan \%K 87,50\% dan \%D 87,17\% hal ini menunjukkan bahwa pada tanggal tersebut adalah kondisi jenuh jual. Kondisi overbought juga terjadi pada tanggal 26 September 2019 dimana garis $\% \mathrm{~K}$ memotong dari atas ke bawah garis $\% \mathrm{D}$ dan berada di atas level 80 sehingga terjadi kondisi jenuh jual.

Tabel 3 Simulasi transaksi perdagangan emas

\begin{tabular}{|c|c|c|c|c|c|c|}
\hline Tanggal & $\begin{array}{c}\text { Biaya } \\
\text { admin }\end{array}$ & Harga beli & $\begin{array}{c}\text { Tanggal } \\
\text { jual }\end{array}$ & Harga jual & Laba & $\%$ Laba \\
\hline $9 / 2 / 2019$ & 1.000 .000 & 98.999 .340 & $9 / 23 / 2019$ & 105.085 .365 & $4.035 .171,35$ & $4,04 \%$ \\
\hline $9 / 2 / 2019$ & 1.000 .000 & 98.999 .340 & $9 / 26 / 2019$ & 104.679 .630 & $3.633 .493,70$ & $3,63 \%$ \\
\hline
\end{tabular}

Diasumsikan pembelian dilakukan pada awal bulan September, yaitu pada tanggal 2 September 2019 dengan modal awal Rp100.000.000,00. Biaya pembelian emas sebesar Rp98.999.340,00 dengan biaya admin sebesar Rp1.000.000 dimana biaya admin yaitu 1\% dari modal awal. Tanggal 23 September 2019 harga jual emas sebesar Rp105.085.365,00 dan mendapatkan laba Rp4.035.171,35. Selanjutnya pada tanggal 26 September 2019 harga jual emas sebesar Rp104.679.630,00 dan mendapatkan laba Rp3.633.493,70.

\section{PENUTUP}

Berdasarkan studi kasus menggunakan data trading emas diketahui bahwa sinyal beli dan sinyal jual pada perusahaan PT. MDKA terdapat dua sinyal dalam periode yang digunakan dua bulan terakhir mulai dari tanggal 2 September 2019 sampai dengan 31 Oktober 2019. Terdapat dua sinyal untuk menjual emas yaitu pada tanggal 23 September 2019 dan 26 September 2019. Pada sinyal beli tidak ada satupun garis $\% \mathrm{~K}$ memotong ke atas garis $\% \mathrm{D}$ dari bawah dan berada pada kondisi oversold atau berada di bawah level 20, sehingga tidak terdapat sinyal beli pada periode dua bulan terakhir. Simulasi pada studi kasus untuk dua bulan terakhir (September-Oktober) dengan asumsi modal awal sebesar Rp100.000.000,00 pembelian emas dilakukan pada awal bulan yaitu tanggal 2 September 2019. Diantara dua sinyal jual tersebut diperoleh keuntungan terbesar dalam menjual emas pada tanggal 23 September 2019 sebesar Rp4.035.171,35. Sehingga diperoleh waktu yang paling tepat untuk melakukan penjualan dalam periode dua bulan terakhir sebaiknya pada tanggal 23 September 2019 karena memiliki keuntungan yang lebih besar diantara sinyal lain. 


\section{DAFTAR PUSTAKA}

[1] Suharto, F.T. Mengungkap Rahasia Forex. Jakarta: PT Elex Media Komputindo; 2013.

[2] Wijaya, R.F. Investasi Saham Ala Swing Trader Dunia. Jakarta: PT Elex Media Komputindo; 2014.

[3] Siswoyo, S. Analisa Fundamental dan Teknikal Untuk Profit Lebih Optimal. Jakarta: PT Gramedia Pustaka Utama; 2013.

[4] Syamsir, H. Solusi Investasi di Bursa Saham Indonesia. Jakarta: PT Elex Media Komputindo; 2004.

[5] Halim, A. Analisis Investasi. Ed ke-2. Jakarta: Salemba Empat; 2005.

[6] Tandelilin, E. Portofolio dan Investasi. Yogyakarta: Kanisus; 2010.

[7] Ong, E. Technical Analysis for Mega Profit. Jakarta: MegaOptions; 2011.

[8] Wira, D. Analisis Teknikal untuk Profit Maksimal. Jakarta: Exceed; 2010.

MILA DAMAYANTI

SETYO WIRA RIZKI

HENDRA PERDANA
: Jurusan Matematika FMIPA UNTAN, Pontianak miladamayanti8@gmail.com

: Jurusan Matematika FMIPA UNTAN, Pontianak setyo.wirarizki@math.untan.ac.id : Jurusan Matematika FMIPA UNTAN, Pontianak hendra.perdana@math.untan.ac.id 